\title{
Prevalence and risk factors for Toxoplasma gondii in sheep in the State of Paraíba, Northeastern Brazil
}

Prevalência de rebanhos positivos e de animais soropositivos e fatores de risco associados com a infecção por Toxoplasma gondii em ovinos no Estado da Paraíba, Nordeste do Brasil

Érico Luís de Barros Correia ${ }^{1}$; Thais Ferreira Feitosa ${ }^{1}$; Fabrine Alexandre dos Santos ${ }^{1}$; Sérgio Santos de Azevedo ${ }^{1}$; Hilda Fátima de Jesus Pena²; Solange Maria Gennari²; Rinaldo Aparecido Mota'; Clebert José Alves ${ }^{1 *}$

\begin{abstract}
${ }^{1}$ Laboratório de Doenças Transmissíveis, Programa de Pós-graduação em Medicina Veterinária, Universidade Federal de Campina Grande - UFCG, Patos, PB, Brasil

${ }^{2}$ Laboratório de Doenças Parasitárias, Programa de Pós-graduação em Epidemiologia Experimental Aplicada às Zoonoses, Universidade de São Paulo - USP, São Paulo, SP, Brasil

${ }^{3}$ Laboratório de Bacterioses, Programa de Pós-graduação em Biociência Animal, Universidade Federal Rural de Pernambuco - UFRPE, Recife, PE, Brasil
\end{abstract}

Received February 8, 2015

Accepted March 12, 2015

\begin{abstract}
The aims of this survey were to determine the flock-level and animal-level prevalences of anti-Toxoplasma gondii antibodies in sheep in the State of Paraíba, Northeastern Brazil, and to identify risk factors. Blood samples were collected from 540 sheep in 63 flocks in 14 municipalities in the Sertão mesoregion. To serologically diagnose T. gondii infection, the indirect immunofluorescent antibody test (IFAT) was used. Flocks with at least one seropositive animal were considered positive. Among the 63 flocks, 28 (44.44\%) were positive, and $60(11.11 \%)$ of the 540 animals were seropositive. Variable flock size $>25$ animals was identified as a risk factor (odds ratio $=3.2 ; 95 \%$ CI $=1.09-9.34$; $P=0.033$ ). The results from this survey demonstrate that $T$. gondii is spread among sheep in the State of Paraíba.
\end{abstract}

Keywords: Toxoplasmosis, small ruminants, serology, epidemiology, control.

\section{Resumo}

Os objetivos deste trabalho foram determinar a prevalência de rebanhos positivos e de animais soropositivos para Toxoplasma gondii em ovinos do Estado da Paraíba, Nordeste do Brasil, bem como identificar fatores de risco. Foram colhidas amostras de sangue de 540 ovinos de 63 rebanhos em 14 municípios da mesorregião do Sertão. Para o diagnóstico sorológico da infecção por T. gondii, foi utilizado o teste de imunofluorescência indireta (RIFI). Rebanhos com pelo menos um animal soropositivo foram considerados positivos. Dos 63 rebanhos, 28 (44,44\%) foram positivos, e 60 (11,11\%) dos 540 animais foram soropositivos. A variável tamanho do rebanho $>25$ animais foi identificada como fator de risco (odds ratio $=3,2 ;$ IC $95 \%=1,09-9,34 ; P=0,033$ ). Os resultados deste trabalho sugerem a disseminação de $T$. gondii em ovinos no Estado da Paraíba.

Palavras-chave: Toxoplasmose, pequenos ruminantes, sorologia, epidemiologia, controle.

\section{Introduction}

The Brazilian national sheep flock is approximately 17 million head, and $56.7 \%$ of this effective are concentrated in the Northeastern region. In the State of Paraiba, sheep farming has economic importance, and this state has a headcount of 433,032 animals distributed in 19,826 farms (IBGE, 2010). In this context, epidemiological investigations of infectious

\footnotetext{
*Corresponding author: Clebert José Alves. Laboratório de Doenças Transmissíveis, Unidade Acadêmica de Medicina Veterinária, Universidade Federal de Campina Grande - UFCG, Av. Universitária, s/n, Santa Cecília, CEP 58700-970, Patos, PB, Brasil.

e-mail: clebertja@uol.com.br
}

and parasitic diseases are of relevance. Among these diseases, toxoplasmosis can be highlighted, given that this is an important cause of abortions among sheep (DUBEY, 2010). Furthermore, the fact that this disease is a widespread zoonosis has to be taken into account.

Toxoplasma gondii is a protozoan parasite with worldwide distribution that can infect a wide range of animal species, including sheep. It has an indirect life cycle with felids as the definitive hosts (DUBEY, 2010). In sheep, T. gondii has been recognized as one of the main causes of infectious ovine abortion in New Zealand, Australia, the United Kingdom, 
Norway and the United States (DUBEY \& BEATTIE, 1988; DUBEY, 2010). This agent is estimated to infect between $4 \%$ and $77 \%$ of the human population (TENTER et al., 2000). Although not normally a significant problem for healthy individuals, $T$. gondii infection can be life-threatening to infants infected congenitally and to immunosuppressed patients (CHINTANA et al., 1998). In animals, T. gondii infection not only results in significant reproduction losses and, hence, economic losses, but also has implications for public health, since consumption of infected meat or milk can lead to zoonotic transmission (DUBEY, 2010).

To date, there have not been any reports of epidemiological investigations relating to toxoplasmosis in sheep in the State of Paraiba, Northeastern Brazil. Therefore, the aims of this survey were to determine the flock-level and animal-level prevalences and to identify the risk factors for $T$. gondii infection among sheep in the State of Paraiba, using a planned sampling.

\section{Materials and Methods}

\section{Sampling}

The sampling was designed for determining the flock-level and animal-level prevalences. The number of flocks to be sampledwas calculated using the formula for simple random sampling (THRUSFIELD, 2007), taking the following parameters into account: expected prevalence of $88.9 \%$, found in the State of Maranhão (BRANDÁO, 2009); 95\% confidence level; and absolute error of $8 \%$. This error was chosen to guarantee the operational capacity of the fieldwork. The number of sheep to be sampledin each flock was determined individually per flock using the formula for detecting the presence of infection (THRUSFIELD, 2007). The probability of detecting at least one seropositive animal in the flock was determined with a $95 \%$ confidence level $(P=0.95)$ and the number of seropositive animals per flock was calculated assuming an intra-flock prevalence of 56.94\% (SAKATA et al., 2012). In total, 540 animals from 63 flocks in 14 municipalities in the Sertão mesoregion were used. Blood sample collection was performed between December 2012 and December 2013.

\section{Serological diagnosis of $T$. gondii infection}

The indirect fluorescent antibody test (IFAT) was used to detect anti- $T$. gondii antibodies, taking the dilution of 1:64 as the cutoff point (GARCIA et al., 1999), in accordance with the method described by Camargo (1974), using as antigens RH strain tachyzoites grown and maintained in Swiss mice. Positive and negative control sheep serum samples were provided by the Laboratory of Parasitic Diseases of the Faculty of Veterinary Medicine, University of São Paulo (USP). Anti-sheep IgG (whole molecule; Sigma, St. Louis, MO, USA) was used as the conjugate at a dilution of 1:400 in sterile PBS (0.105 $\mathrm{M} \mathrm{Na}_{2} \mathrm{HPO}_{4}, 0.018 \mathrm{M} \mathrm{KH}_{2} \mathrm{PO}_{4}$, $1.37 \mathrm{M} \mathrm{NaCl}$ and $0.027 \mathrm{M} \mathrm{KCl}$ ), at $\mathrm{pH}$ 7.6.

\section{Statistical analysis}

Flocks with at least one seropositive animal were considered positive. For the risk factor analysis, data gathered through epidemiological questionnaires that had been applied to each farm owner were used. The analysis was performed in two steps: univariable and multivariable analyses. Univariable analysis was performed using the chi-square test or Fisher's exact test (ZAR, 1999), and variables that presented $P \leq 0.20$ were used for multivariable logistic regression. Multivariable analysis was then performed, using the stepwise forward method (HOSMER \& LEMESHOW, 2000). The significance level in the multivariable analysis was $5 \%$. The collinearity among independent variables was assessed using correlation analysis, and when two variables were highly collinear (correlation coefficient $>0.90$ ), only one variable was likely to enter the multivariable analysis. In such situations, selection of which collinear variable to put into the model was guided by biological plausibility (DOHOO et al., 1997). The tests were performed using the SPSS software package, version 13.0 for Windows.

\section{Results and Discussion}

Among the 63 flocks, $28(44.4 \%)$ presented at least one seropositive sheep, and among the 540 sheep used, 60 were seropositive for T. gondii, thus resulting in a prevalence of $11.1 \%$ with antibody titers ranging from 64 to 2,048. Sakata et al. (2012) found a seroprevalence of 56.94\% among sheep in the municipality of Lages, State of Santa Catarina. This high prevalence, in comparison to that obtained in the present study, may be explained by the high humidity of the Lajes region, with greater and more regular rainfall, which may contribute towards higher viability among $T$. gondii oocysts in the environment. On the other hand, Pereira et al. (2012) and Andrade et al. (2013) found prevalence rates of $16.9 \%$ and $26.29 \%$ among sheep in the States of Pernambuco and Rio Grande do Norte, respectively, which are both located in the semiarid region of Brazil.

Even though the prevalence of seropositive animals was low, there was at least one seropositive animal in $44.4 \%$ of the flocks. This demonstrates that this agent is spread in the region. In this context, it should be noted that the sheep-rearing profile in this region consists of extensive and semi-intensive management systems, in which the animals are set free during the day and are gathered into rustic pens at night, lacking basic infrastructure, with inadequate hygiene practices. This demonstrates that there is a need to apply appropriate technologies to the realities of sheep farming in the semiarid region. Absence of technification, such as practicing regular cleaning of the installations and reproductive management during the postpartum period, may facilitate the contact with $T$. gondii oocysts present in the environment (TENTER et al., 2000).

In the risk factor analysis, the variables of purpose of rearing $(P=0.164)$, technified rearing $(P=0.066)$, flock size $(P=0.066)$ and occurrences of abortions $(P=0.081)$ were selected from the univariable analysis (Table 1 ). In the multivariable analysis, the variable of flock size $>25$ animals was identified as a risk factor 
Table 1. Univariable analysis on risk factors associated with flock-level prevalence of Toxoplasma gondii infection in sheep, in the State of Paraiba, Northeastern Brazil, from December 2012 to December 2013.

\begin{tabular}{|c|c|c|c|}
\hline Variable & $\begin{array}{c}\text { Total } \\
\text { number of } \\
\text { flocks }\end{array}$ & $\begin{array}{c}\text { Number } \\
\text { of positive } \\
\text { flocks (\%) }\end{array}$ & $P$ \\
\hline \multicolumn{4}{|l|}{ Management system } \\
\hline Intensive & 1 & $1(100)$ & \\
\hline Extensive & 43 & $17(39.5)$ & \\
\hline Semi-intensive & 19 & $11(57.9)$ & 0.225 \\
\hline \multicolumn{4}{|l|}{ Purpose of rearing } \\
\hline Breeding & 18 & $7(38.9)$ & \\
\hline Raising/fattening & 30 & $15(50)$ & \\
\hline Reproduction & 4 & $3(75)$ & \\
\hline Subsistence & 11 & $2(18.2)$ & $0.164^{*}$ \\
\hline \multicolumn{4}{|l|}{ Type of exploitation } \\
\hline Meat & 54 & $25(46.3)$ & \\
\hline Milk & 2 & $1(50)$ & \\
\hline Others & 7 & $3(42.9)$ & 0.979 \\
\hline \multicolumn{4}{|l|}{ Technified rearing } \\
\hline No & 54 & $21(38.9)$ & \\
\hline Yes & 9 & $7(77.8)$ & $0.066^{*}$ \\
\hline \multicolumn{4}{|c|}{ Major activity on the farm } \\
\hline No & 48 & $20(41.7)$ & \\
\hline Yes & 15 & $9(60)$ & 0.344 \\
\hline \multicolumn{4}{|l|}{ Flock size } \\
\hline Up to 25 animals & 35 & $12(34.3)$ & \\
\hline$>25$ animals & 28 & $17(60.7)$ & $0.066^{*}$ \\
\hline \multicolumn{4}{|c|}{ Contact with other animals } \\
\hline No & 26 & $10(38.5)$ & \\
\hline Yes & 37 & $19(51.4)$ & 0.451 \\
\hline \multicolumn{4}{|l|}{ Native pasture } \\
\hline No & 1 & $1(100)$ & \\
\hline Yes & 62 & $28(45.2)$ & 0.460 \\
\hline \multicolumn{4}{|c|}{ Mineral supplementation } \\
\hline No & 34 & $13(38.2)$ & \\
\hline Yes & 29 & $13(44.8)$ & 0.785 \\
\hline \multicolumn{4}{|l|}{ Animal purchases } \\
\hline No & 30 & $12(40)$ & \\
\hline Yes & 33 & $16(48.5)$ & 0.672 \\
\hline \multicolumn{4}{|l|}{$\begin{array}{l}\text { Participation in animal } \\
\text { agglomerations }\end{array}$} \\
\hline No & 60 & $24(40)$ & \\
\hline Yes & 3 & $2(66.7)$ & 0.564 \\
\hline \multicolumn{4}{|c|}{ Occurrences of abortions } \\
\hline No & 41 & $22(53.7)$ & \\
\hline Yes & 22 & $6(27.3)$ & $0.081^{*}$ \\
\hline \multicolumn{4}{|c|}{ Occurrences of stillbirths } \\
\hline No & 40 & $18(45)$ & \\
\hline Yes & 23 & $7(30.4)$ & 0.384 \\
\hline \multicolumn{4}{|l|}{$\begin{array}{l}\text { Occurrences of death at } \\
\text { weaning }\end{array}$} \\
\hline $\mathrm{No}$ & 47 & $20(42.5)$ & \\
\hline Yes & 18 & $6(33.3)$ & 0.692 \\
\hline
\end{tabular}

*Variables selected for the multivariable analysis $(P \leq 0.20)$. (odds ratio $=3.2 ; 95 \% \mathrm{CI}=1.09-9.34 ; P=0.033$ ). This indicator reinforces the argument that the risk of introduction and spreading of diseases and, consequently, occurrence of economic losses in sheep production is greater when the flock size is larger, however, variables related to herd size are not liable of correction, and in this case, an adequate sanitary planning assumes an important role as a control measure.

Regarding occurrences of abortions, although this variable was not associated with $T$. gondii prevalence in the multivariable analysis, the frequency of positivity was greater in flocks with no reports of abortions $(53.7 \%)$ than in flocks with history of abortions (27.3\%) (Table 1), with an odds ratio of 3.09 $(95 \% \mathrm{CI}=1.01-9.48)$ (data not shown). This situation raises the awareness that is a need of analysis in which the matter of sub-notification of abortions can be taken into consideration, particularly with regard to extensive rearing systems. The predominance of extensive systems under semiarid conditions, in association with precarious management practices and absence of a zootechnical register, contribute towards ineffective monitoring of events relating to reproductive problems. This may make it difficult to evaluate the productive and economic performance.

\section{Conclusion}

We concluded that $T$. gondii infection is spread among sheep in the State of Paraíba, Northeastern Brazil, and our findings suggest that the implementation of adequate sanitary planning is necessary to avoid the spreading of the infection and, consequently, occurrence of economic losses in sheep production.

\section{References}

Andrade MMC, Carneiro M, Medeiros AD, Andrade Neto V, Vitor RWA. Seroprevalence and risk factors associated with ovine toxoplasmosis in Northeast Brazil. Parasite 2013; 20(20). PMid:23707895.

Brandão VM. Avaliação soroepidemiológica de anticorpos anti - Toxoplasma gondii em rebanhos caprinos e ovinos na ilha de São Luis - MA [Dissertação]. São Luís: Universidade Estadual do Maranhão; 2009.

Camargo ME. Introdução às técnicas de imunofluorescência. Rev Bras Patol Clin 1974; 10(3): 143-171.

Chintana T, Sukthana Y, Bunyakai B, Lekkla A. Toxoplasma gondii antibody in pregnant women with and without HIV infection. Southeast Asian J Trop Med Public Health 1998; 29(2): 383-386. PMid:9886133.

Dohoo IR, Ducrot C, Fourichon C, Donald A, Hurnik D. An overview of techniques for dealing with large numbers of independent variables in epidemiologic studies. Prev Vet Med 1997; 29(3): 221-239. http://dx.doi. org/10.1016/S0167-5877(96)01074-4. PMid:9234406.

Dubey JP, Beattie CP. Toxoplasmosis of animals and man. Boca Raton: CRC Press; 1988.

Dubey JP. Toxoplasmosis of animals and humans. 2nd ed. Boca Raton: CRC Press; 2010.

Garcia JL, Navarro IT, Ogawa L, Oliveira RC. Soroepidemiologia da toxoplasmose em gatos e cães de propriedades rurais do município de Jaguapitã, Estado do Paraná, Brasil. Cienc Rural 1999; 29(1): 99-104. http://dx.doi.org/10.1590/S0103-84781999000100018. 
Hosmer DW, Lemeshow S. Applied logistic regression. New York: John Wiley \& Sons; 2000. http://dx.doi.org/10.1002/0471722146.

Instituto Brasileiro de Geografia e Estatística - IBGE. Sistema IBGE de Recuperação Automática - SIDRA [online]. Brasília; 2010 [cited 2014 Sep 9]. Available from: http://www.sidra.ibge.gov.br/bda

Pereira MF, Peixoto RM, Langoni H, Greca H Jr, Azevedo SS, Porto WJN, et al. Fatores de risco associados à infecção por Toxoplasma gondii em ovinos e caprinos no estado de Pernambuco. Pesqui Vet Bras 2012; 32(2): 140-146. http://dx.doi.org/10.1590/S0100-736X2012000200009.

Sakata FBLS, Bellato V, Sartor AA, Moura AB, Souza AP, Farias JA. Toxoplasma gondii antibodies sheep in Lages, Santa Catarina, Brazil, and comparison using IFA and ELISA. Rev Bras Parasitol Vet 2012; 21(3): 196-200. http://dx.doi.org/10.1590/S1984-29612012000300004. PMid:23070426.

Tenter AM, Heckeroth AR, Weiss LM. Toxoplasma gondii: from animals to humans. Int J Parasitol 2000; 30(12-13): 1217-1258. http://dx.doi. org/10.1016/S0020-7519(00)00124-7. PMid:11113252.

Thrusfield M. Veterinary epidemiology. 3rd ed. Oxford: Blackwell Science; 2007.

Zar JH. Biostatistical analysis. 4th ed. Upper Saddle River: Prentice Hall; 1999. 